Published in final edited form as:

Infect Dis Clin North Am. 2008 September ; 22(3): 469-ix. doi:10.1016/j.idc.2008.03.010.

\title{
Human Babesiosis
}

Edouard Vannier, PhDa, Benjamin E. Gewurz, MD, PhD ${ }^{\mathrm{b}}$, and Peter J. Krause, MDc,d

${ }^{a}$ Assistant Professor of Medicine, Division of Geographic Medicine and Infectious Diseases, Tufts-New England Medical Center, Tufts University School of Medicine, Boston, Massachusetts

${ }^{b}$ Fellow in Infectious Diseases, Brigham and Women's Hospital, Harvard Medical School, Boston, Massachusetts

'Professor of Pediatrics, University of Connecticut School of Medicine, Farmington, Connecticut

dDirector, Division of Infectious Diseases, Connecticut Children's Medical Center, Hartford, Connecticut

\section{Keywords}

babesiosis; babesia; parasitemia; erythrocyte; tick-borne; Ixodes scapularis

\section{Introduction}

Human babesiosis is an emerging tick-borne infectious disease caused by protozoa of the genus Babesia that are obligate parasites of red blood cells. Long recognized as pathogens imposing a significant health burden on domesticated animals, Babesia spp. increasingly have been identified over the last 50 years as a cause of infection in people throughout the world.

The first reference to babesiosis is probably in Exodus 9:3, which describes the plague visited upon the cattle of Pharaoh Rameses II. Viktor Babes, a Hungarian pathologist who investigated the cause of febrile hemoglobinuria in cattle grazing in the Danube region of Romania, was the first to document a microorganism residing in red blood cells.[1] Shortly thereafter, Smith and Kilborne identified a similar organism in Texas cattle.[2] Named Pyrosoma bigeminum after its pear shape, the protozoan was later recognized as Babesia bigemina. The cattle tick, Boophilus annulatus, was identified as the vector for transmission of Texas cattle fever. By making this seminal observation, Smith and Kilborne established

(c) 2008 Elsevier Inc. All rights reserved.

${ }^{\mathrm{c}, \mathrm{d}}$ Corresponding author for proof and reprints: Peter J. Krause, MD, Division of Infectious Diseases, Connecticut Children's Medical Center, 282 Washington Street, Hartford, Connecticut 06106, (860) 545-9490, (860) 545-9371 (fax), PKrause@ ccmckids.org. a, ${ }_{\text {Co-authors addresses: }}$

Edouard Vannier, PhD, Division of Geographic Medicine, and Infectious Diseases, Tufts-New England Medical Center, 750 Washington Street, Boston, Massachusetts 02111, (617) 636-8526, EVannier@tufts-nemc.org

Benjamin E. Gewurz, MD, PhD, Division of Infectious Diseases Brigham and Women's Hospital, 75 Francis Street, Boston, Massachusetts 02115, (617) 732-8881,BGewurz@ partners.org

Publisher's Disclaimer: This is a PDF file of an unedited manuscript that has been accepted for publication. As a service to our customers we are providing this early version of the manuscript. The manuscript will undergo copyediting, typesetting, and review of the resulting proof before it is published in its final citable form. Please note that during the production process errors may be discovered which could affect the content, and all legal disclaimers that apply to the journal pertain. 
the concept that hematophagous arthropods can transmit an infectious agent to vertebrate hosts. More than 100 species of babesia subsequently have been identified in wild and domestic animals.[3]

The first human case of babesiosis was identified in 1957 near Zagreb, Croatia.[4] A young farmer had been grazing cattle on tick-infested pastures and presented with fever, anemia and hemoglobinuria. He was asplenic and died of renal insufficiency during the second week of illness. Initially reported as Babesia bovis, the agent most likely was Babesia divergens, another pathogen of cattle. In 1968, B. divergens was confirmed as the etiologic agent in an asplenic person infected while vacationing in the Irish countryside.[5] While these asplenic cases were attracting the attention of physicians in Europe, babesiosis was diagnosed in several residents of Nantucket Island, off the coast of Massachusetts. The causative agent was determined to be Babesia microti, which typically infects mice and other small rodents.[6] Spielman and colleagues subsequently identified the vector as Ixodes dammini (also known as I. scapularis) and recognized the white-tailed deer (Odocoileus virginianus) as an important natural host.[7-10] In the 1990's, Babesia duncani (WA1) was identified in human cases reported from the northern Pacific coast,[11] and a B. divergenslike organism in a case from Missouri (MO1).[12] Another Babesia spp. was identified in asplenic patients from the Tyrol region of Austria and the Alpine region of Italy in 2003.[13] They experienced a severe illness caused by EU1, a species closely related to $B$. odocoilei and known to infect white-tailed deer. Additional babesial species infecting humans have been identified in Taiwan (TW1)[14] and Korea (KO1).[15] Initially diagnosed in Europe and North America, human babesiosis is now reported from around the world.

\section{Epidemiology}

\section{The pathogen}

Babesia spp. are in the phylum Apicomplexa, together with organisms that cause malaria (Plasmodium spp.), toxoplasmosis (Toxoplasma gondii), and cryptosporidiosis

(Cryptosporidium). The name Apicomplexa is derived from the complex of unique organelles located in the cellular apex of certain life stages of these protists. The apical complex includes vesicles called rhoptries and micronemes that secrete enzymes allowing the parasite to invade host cells.[16]

Babesia spp. have a complex life cycle that involves asexual reproduction in the erythrocytes of their mammalian hosts and sexual reproduction in their arthropod vector (www.dpd.cdc.gov/dpdx/HTML/Babesiosis.htm). Within the red blood cell, trophozoites reproduce by budding rather than schizogony. B. microti and B. duncani may undergo two successive divisions. The four resulting nuclei remain in close proximity and this merozoite tetrad form is described as a "Maltese Cross". B. divergens merozoites undergo a single division. Egress of merozoites and lysis of red blood cells appear to occur simultaneously. Free merozoites in the bloodstream attach and invade other red blood cells. Some of the host intraerythrocytic forms are gametocytes that contain twice as much DNA and are morphologically distinct from trophozoites.[17, 18] Gametocytes ingested by ticks during the blood meal emerge from erythrocytes within the gut, and fuse to form an ookinete that penetrates the gut epithelium. Ookinetes invade the tick salivary glands and other tissue, 
then transform into sporoblasts that remain dormant through the molt of the engorged tick. [19] When the next stage of the tick (nymph or adult) takes a blood meal from a vertebrate host, sporoblasts are activated and begin a sporogonic process. Each sporoblast may liberate up to 10,000 sporozoites, which enter the salivary ducts of the tick, and are deposited into the skin of the infested vertebrate.[20]

\section{Transmission}

B. microti is the most common cause of human babesiosis. The primary tick vector of this species is I. scapularis.[10] The primary reservoir for B. microti in eastern North America is the white-footed mouse (Peromyscus leucopus). $[7,10]$ As many as two-thirds of mice have been found to be parasitemic in endemic areas.[10] These mice also may be infected with Borrelia burgdorferi, the etiologic agent of Lyme disease, and Anaplasma phagocytophilum, the agent of human granulocytic anaplasmosis. I. scapularis may acquire B. microti, $B$. burgdorferi, and/or A. phagocytophilum during a blood meal and subsequently transmit these pathogens.[10,21]

Each of the three active stages in the life cycle of I. scapularis (larva, nymph, and adult) takes a blood meal from a vertebrate host in order to mature to the next stage (Figure 1). The tick transmission cycle begins in the spring when adult females lay eggs that hatch into larvae. In the late summer, newly hatched larvae ingest the parasite with a blood meal from an infected rodent and molt to the nymphal stage. Nymphs transmit babesia to rodents in late spring and summer of the following year.[7, 10] Larvae, nymphs, and adults can feed on humans, but nymphs are the primary vector.[22] All active tick stages also feed on the white-tailed deer (Odocoileus virginianus), which is an important host for the tick but is not a reservoir for B. microti.[10] Because deer serve to amplify the number of ticks, the growth of the deer population over the past few decades is thought to be the major cause for the increase in human cases.[7, 10,23] Babesiosis is rarely acquired through blood transfusions and a few cases of transplacental/perinatal transmission have been described.[24-26]

\section{Human epidemiology}

Over the past 50 years, the epidemiology of the human babesiosis has changed from a few isolated cases to the establishment of endemic areas in southern New England, New York, and the north central Midwest. Human babesiosis due to B. microti has been reported in Connecticut, Massachusetts, Minnesota, New Jersey, New York, Rhode Island, and Wisconsin.[6-10, 24, 27-31] Moderately severe illness caused by $B$. duncani occurs in Washington state and California.[11, 32] Cases of $B$. divergens-like infection have been reported from Missouri,[12] Kentucky,[33] and Washington state.[34] In Europe, $B$. divergens, B. microti, and EU1 have been reported to cause babesiosis in people and are thought to be transmitted by Ixodes ricinus.[13, 35-38] In Asia, babesiosis has been reported in Japan (B. microti-like),[39] Korea (KO1),[15] Taiwan (TW1),[14] and India.[40] Human babesiosis also has been reported in Africa[41] and South America.[42]

Although the babesial piroplasm and Lyme spirochete share the same reservoir hosts and tick vectors, human babesiosis only has been recognized in concentrated foci within Lyme disease-endemic areas and the number of reported cases of babesiosis is less than that of 
Lyme disease in these foci.[43] B. burgdorferi infection is more commonly found in ticks and rodents than B. microti or A. phagocytophilum in regions where all three infections are endemic.[44] Unlike Lyme disease, babesiosis is not a nationally reportable disease. Lyme disease is better recognized and more easily diagnosed than babesiosis, primarily because of the pathognomonic erythema migrans rash, whereas symptoms and signs of babesiosis are non-specific and easily mistaken for a viral illness.[45] Nonetheless, results of a detailed epidemiologic study of babesiosis and Lyme disease suggest that the disparity in the frequency of these infections on the southern New England coast is markedly less than would be expected from current epidemiologic data.[43] The public health burden of babesiosis is incompletely described but may be significant in certain endemic sites. Nantucket Island reported 21 cases in 1994, which translates to 280 cases per 100,000 inhabitants, placing the burden of disease in a category with gonorrhea as "moderately common".[46] Furthermore, babesiosis may be increasing in incidence relative to Lyme disease. In the early 1990's on Block Island, Rhode Island, the incidence of B. microti infection increased approximately four-fold while that of B. burgdorferi remained essentially unchanged.[43] Most human cases of babesiosis occur in the summer and in areas where the vector tick, rodents, and deer are in close proximity to humans.[10] Although the majority of cases are reported in adults, there is evidence that the disease is more common in children than is currently reported.[43]

\section{Clinical manifestations}

Patients may experience a spectrum of disease severity and three distinct syndromes have been described, (i) mild to moderate viral-like illness, (ii) severe disease with a fulminant course resulting in death or a persistent relapsing course, and (iii) asymptomatic infection. Limited data suggest that symptoms of babesiosis begin one to six weeks after tick feeding.

\section{Mild to moderate illness}

Most cases of babesiosis consist of a mild to moderate illness characterized by the gradual onset of malaise and fatigue followed by intermittent fever and one or more of the following: chills, sweats, headache, arthralgia, myalgia, anorexia, and cough (Table 1).[21, 47-49] Less commonly noted are sore throat, abdominal pain, nausea, vomiting, weight loss, conjunctival injection, photophobia, pallor, emotional lability, depression, and hyperesthesia.[50, 51] The findings on physical examination generally are minimal, often consisting only of fever.[21, 48] Mild splenomegaly, hepatomegaly, or both are noted occasionally.[48, 52] Slight pharyngeal erythema, jaundice, and retinopathy with splinter hemorrhages and retinal infarcts also have been reported.[53, 54] Rash seldom is noted, although ecchymoses and petechiae have been described in severe cases.[51] The illness usually lasts for several weeks to months, occasionally with prolonged recovery that can last more than a year.[21, 48, 55, 56] Parasitemia may continue even after the patient feels well and rarely may persist for more than two years after the initial episode.[56]

\section{Severe disease}

Severe disease generally occurs in people with underlying immunosuppressive conditions that include HIV coinfection,[57-59] malignancy,[55] immunosuppressive medication,[55, 
60] and splenectomy.[55, 61, 62] In a recent case control study, patients with more than one of these immunosuppressive conditions were shown to experience a prolonged, relapsing course of illness, sometimes lasting more than a year.[55] Despite multiple courses of antibabesial therapy, a fifth of these patients died. People 50 years of age and older are also more likely to experience severe babesiosis.[47, 49] Recent studies using a babesia mouse model suggest that advanced age is not universally associated with more severe parasitemia and that age related severity may be genetically determined.[63] Microbial virulence also may account for disease severity. B. divergens and B. duncani appear to cause more severe infection than that caused by B. microti.[11, 64] Finally, patients experiencing babesiosis who are coinfected with B. burgdorferi also have more severe acute illness.[21, 45]

Complications of babesiosis are commonly associated with severe illness and include acute respiratory failure, DIC, congestive heart failure, liver and renal failure, and splenic infarction (Table 2). In a review of 34 consecutive babesial patients admitted to the hospital (median age of 43 years, range 3 months to 85 years), the most common complication was acute respiratory failure.[47] Nine percent of these hospitalized patients died. A mortality rate of 5 percent was noted in a retrospective study of 136 patients experiencing $B$. microti infection on Long Island, New York.[30] In that study, patients who suffered fatal infection ranged from 60 to 82 years and only one was known to be immunocompromised.

\section{Asymptomatic infection}

Patients who develop symptomatic babesiosis experience an initial subclinical infection during the first few weeks following the bite of an infected tick. After symptoms have resolved, asymptomatic parasitemia may persist for months or years.[56] It is well recognized that many people who are infected with $B$. microti never experience any symptoms, as indicated by the disparity between seroprevalence and the number of indigenous reported cases.[48] A survey of adults living on Shelter Island, New York, showed that 6 of 102 (5.9 per cent) had B. microti IFA antibody at titers of $\geq 1: 64$.[65] Similar disparities were noted in serosurveys in Connecticut, Massachusetts, and Taiwan. $[29,48,66]$ An estimate of the actual rate of asymptomatic babesial infection can be derived from an intensive epidemiologic study of babesiosis carried out on Block Island, Rhode Island.[43] Symptomatic babesial cases were identified by physicians at the Block Island Medical Center. Asymptomatic babesial infections were identified among healthy residents participating in an annual serosurvey who reported no babesial-like illness but seroconverted against $B$. microti antigen during the previous year. Overall, about one third of babesial infections on Block Island were asymptomatic, including 19\% (13 of 67) of adults and 40\% (4 of 10) of children.[43] It is uncertain whether patients experiencing asymptomatic babesial infection are at risk for any complications, although such carriers may transmit the infection if they donate blood.[26] Long-term asymptomatic infection of natural hosts increases the probability of transmission to arthropod vectors and to new hosts, thereby assuring pathogen survival.

\section{Pathogenesis}

Two major processes underlie the pathogenesis of babesiosis: red blood cell modification by the pathogen, and the host immune response to the pathogen. 


\section{Red blood cell modification}

The only cells infected by Babesia spp. are erythrocytes. A study of B. bovis infection revealed that variable merozoite surface antigens (VMSA) mediate the attachment of free merozoites and sporozoites to red blood cells.[67] Heparin sulfate-like glycosaminoglycans and sialoglycoproteins on the surface of red blood cells also are engaged.[67, 68] After reorientation of the merozoite, proteins are secreted from rhoptries and micronemes that mediate parasite entry into the erythrocyte.[67] The parasite reproduces by binary fission, generating as many as four merozoites. The egress of merozoites eventually leads to the loss of red blood cell membrane integrity. As the infection progresses, hemolytic anemia develops and may be accompanied by tissue hypoxia.

As with Plasmodium spp., Babesia spp. export proteins that are incorporated into the red blood cell membrane. Like the $P$. falciparum erythrocyte membrane protein1 (PfEMP1), the variant erythrocyte antigen 1 (VESA1) of $B$. bovis appears to be encoded by a highly polymorphic gene.[69] Such polymorphisms are thought be beneficial to the parasite, as the expression of different variants over the course of infection allows the parasite to escape the immune response mounted by the host.[70, 71] VESA1 appears to promote cytoadherence of infected red blood cells to the vascular endothelium, although the evidence is less compelling than for PfEMP1.[72] Cytoadherence is thought to facilitate persistent infection, perhaps by diminishing access to host immune cells or preventing removal of infected erythrocytes in the spleen.[73] In B. bovis and B. duncani infections, excessive cytoadherence and sequestration lead to microvascular obstruction and tissue hypoxia. [74-76] Erythrocyte cytoadherence and sequestration are yet to be documented in B. microti or $B$. divergens infections. $[77,78]$

\section{Host immune response}

The host immune response is required to control and clear Babesia infected red blood cells but also may cause pathology. Cytokines are central to both aspects of the immune response. Sequential cytokine gene expression is thought to confer protective immunity, with expression of the inflammatory cytokines IL-12 and IFN- $\gamma$ preceding expression of the antiinflammatory cytokines IL-4 and IL-10.[79, 80] In mice infected with $B$. duncani, IFN- $\gamma$ is required for survival.[81] In mice infected with $B$. microti, a lack of IFN- $\gamma$ increases peak parasitemia, and prolongs or prevents resolution of parasitemia.[82, 83] $\mathrm{CD}^{+} \mathrm{T}$ cells are the main source of IFN- $\gamma$ in B. microti infection,[83] but do not appear to contribute to resistance in $B$. duncani infection.[81] In contrast, NK cells are the main source of IFN- $\gamma$ in B. duncani infection,[81] but are not required for resistance in B. microti infection.[84] IFN$\gamma$, in synergy with inflammatory cytokines such as TNF-a, activates macrophages to produce nitric oxide that kills intracellular parasites. $[81,85,86]$ Merozoites themselves also can induce inflammatory cytokines and nitric oxide.[86, 87] The fine-tuning of IFN- $\gamma$ and TNF- $a$ by the anti-inflammatory cytokines IL- 4 and IL-10[88] may ensure that the inflammatory reaction remains mainly localized to the spleen, thereby limiting a generalized systemic inflammatory reaction. As a stronger inflammatory reaction is required to contain and resolve a more severe infection, the inflammatory reaction may spill into the systemic compartment, thereby generating a sepsis-like syndrome or evoking the adult respiratory distress syndrome. 
Pulmonary inflammation is the most common complication in people experiencing severe $B$. microti infection with up to $20 \%$ of patients suffering from non-cardiac pulmonary edema.

[47] Edema and inflammation also have been noted in the lungs of $B$. duncani infected mice. [89] IFN- $\gamma$ is detected around and within the pulmonary vessels whereas TNF- $\alpha$ is mostly localized to the alveolar septa.[89] In this model, infection with $B$. duncani is fatal but blockade of TNF-a can prevent death. Excess cytokine production is thought to be a major cause of severe babesial disease and is associated with tissue pathology that can lead to significant end-organ damage.[90, 91]

Immunosuppressed patients experiencing babesiosis generally suffer severe disease. The nature of the immunosuppression provides useful insights regarding the immune cells critical for host resistance. Patients with immunosuppressive conditions that primarily affect the $\mathrm{CD} 4^{+} \mathrm{T}$ cell compartment, such as HIV/AIDS, may develop fulminant and persistent $B$. microti infection.[55, 57-59] Elderly individuals who are known to experience a progressive contraction of the naïve $\mathrm{CD} 4^{+} \mathrm{T}$ compartment are predisposed to severe, sometimes fatal $B$. microti infection.[47, 49] The importance of $\mathrm{T}$ cells, particularly $\mathrm{CD}^{+} \mathrm{T}$ cells, has been confirmed in mouse models of $B$. microti infection.[83, 92-94] On the other hand, virtually every person who resolves their babesial infection develops specific antibabesial antibody, implying that antibodies help clear infected red blood cells. In addition, patients who suffer from lymphoproliferative disorders of the B cell compartment and are treated with regimens that deplete B cells also are at risk for persistent or relapsing babesiosis,[55] suggesting an important role for B cells in host resistance. However, studies of B. microti infection in mice do not provide strong evidence of a role for B cells and immunoglobulins in host resistance, [82, 95-97] implying that additional immune dysfunction is required for symptomatic babesiosis to develop in patients with B cell proliferative disorders.

\section{Diagnosis}

\section{Clinical diagnosis}

The diagnosis of babesiosis requires strong clinical suspicion, as the symptoms of babesial infection may overlap with those of several other illnesses. There are no pathognomonic signs on physical exam. Babesiosis should be considered when individuals present with viral-like symptoms and have recently spent time outdoors in a babesial endemic area during the summer or early autumn months. With changes in climate patterns, the season during which new babesiosis cases occur may extend. Babesiosis also should be considered in individuals with Lyme disease or human granulocytic anaplasmosis, as any combination of the three infections can be transmitted simultaneously by I. scapularis.[45] A workup for babesiosis should be initiated in patients who experience a viral-like illness without alternative diagnosis that begins within 2 months following a blood transfusion.

\section{Laboratory diagnosis}

Non-specific laboratory findings of babesiosis reflect lysis of erythrocytes. These may include a normocytic hemolytic anemia, with hyperbilirubinemia and an elevated indirect bilirubin fraction, elevated serum lactate dehydrogenase (LDH), and decreased serum haptoglobin. An elevated reticulocyte count and thrombocytopenia are commonly observed. 
[45] Leukocyte counts are generally normal to slightly decreased, with a left-shift. Elevated transaminase and alkaline phosphatase are noted in about half the patients.[49] Proteinuria and elevated blood urea nitrogen and creatinine also may occur in severe cases. Urinalysis may likewise reflect hemolysis, with hemoglobinuria.

Definitive diagnosis of babesial infection generally is made by microscopic identification of the organism (Figure 2) on Giemsa or Wright stains of thick and thin blood smears.[98] Babesia species may appear as round, oval, or pear-shaped forms, with blue cytoplasm and red chromatin. Multiple parasites may be present in infected red blood cells. The ring form is most common and is similar to that of P. falciparum. Distinguishing features of babesiosis on smear include the presence of extra-erythrocytic forms in severe cases and the absence of pigment deposits (hemozoin) typically seen in older ring stages of $P$. falciparum. Tetrads of merozoites arranged in a 'Maltese Cross' are pathognomonic for babesiosis but rarely are seen.[98] The percent of infected erythrocytes varies over the course of infection. Often less than $1 \%$ of erythrocytes are parasitized early in the course of illness. Thus, multiple blood smears may need to be examined over several days to identify parasite forms.

If the suspicion of babesiosis remains high despite negative smears, babesial DNA from blood samples may be amplified using the polymerase chain reaction (PCR).[99, 100] PCR provides a highly sensitive and specific, albeit expensive test for detecting babesial DNA in blood.[99, 100] Babesial DNA may be amplified for months after initial infection despite standard treatment and resolution of clinical illness.[56] Rigorous precautions are required to avoid false-positive PCR results. Serology is also useful in confirming babesial diagnosis. Anti-babesial IgM and IgG antibodies can be detected by indirect immunofluorescence assay (IFA).[101-103] A babesial IFA titer of $\geq 1: 1024$ usually signifies active or recent infection.[103] Titers generally return to $\leq: 64$ within 8 to 12 months but may persist for years.[56, 103] In rare circumstances when the conventional tests are negative but babesiosis remains a possibility, the diagnosis may be made by injection of patient blood into hamsters, as an intense parasitemia will develop 2 to 4 weeks after inoculation of this highly susceptible host.[104]

\section{Treatment}

Patients who experience symptomatic babesiosis should be given a course of antimicrobial therapy upon confirmation of the diagnosis by blood smear or PCR.[52, 105, 106] Two commonly used antimicrobial regimens are highly effective: the combination of atovaquone and azithromycin and the combination of clindamycin and quinine (Table 3).

\section{Mild to moderate illness}

Atovaquone and azithromycin administered for 7 to 10 days is the regimen of choice for mild to moderate babesiosis. Alternatively, clindamycin and quinine may be given, however, adverse affects associated with this combination occur at a relatively high frequency during treatment of babesiosis. In particular, tinnitus and gastroenteritis limit the ability of many patients to tolerate this regimen. The two regimens were directly compared in adults in a prospective, nonblinded randomized control trial.[105] While these drug combinations were similarly effective in clearing parasitemia and achieving resolution of symptoms, adverse 
effects were reported in 15\% of subjects who received atovaquone and azithromycin compared with $72 \%$ of subjects who received clindamycin and quinine. Furthermore, about one third of subjects taking clindamycin and quinine suffered from adverse reactions that were severe enough to require a decrease in dosage or discontinuing the medication. In contrast, only $2 \%$ of subjects taking atovaquone and azithromycin experienced such severe drug reactions. Although atovaquone and azithromycin has not been studied in a controlled trial for pediatric use, cure has been achieved with use of this regimen in children.[25, 107]

\section{Severe disease}

In patients with severe disease, the combination of clindamycin (administered intravenously) and quinine given for 7 to 10 days is the treatment of choice (Table 3).[52, 106] Although other drugs have proven ineffective in experimental models of babesial infection or in human babesiosis, the combination of pentamidine and trimethoprim-sulfamethoxazole was used successfully to treat a case of $B$. divergens infection.[108] B. divergens infections are consistently described as life threatening and clindamycin and quinine should be used for all such cases, in addition to exchange blood transfusion.[64] Exchange red blood cell transfusion is indicated for all babesiosis patients experiencing heavy parasitemia ( $\geq 10 \%)$ or who have significant pulmonary, renal, or hepatic compromise.[47, 109-111] Partial or complete exchange transfusion rapidly decreases parasite burden and removes toxic byproducts of babesial infection.

Despite standard combination antimicrobial therapy, persistent relapsing babesial infection may develop in people with significant underlying immunosuppression.[55] Atovaquoneproguanil (250mg-50mg) was used to eradicate parasitemia in one such patient.[112] In a recent case-control study of chronic babesiosis in 14 highly immunocompromised patients, no single antimicrobial combination was uniformly effective in achieving resolution of infection.[55] Rather, cure was associated with duration of therapy for a minimum of six weeks and for at least two weeks after the last positive blood smear. Interestingly, the majority of case patients in the study had underlying B-cell lymphoma and had been treated with the anti-CD20 monoclonal antibody rituximab prior to acute babesial infection, further impairing their B-cell compartment. Future studies are required to determine whether humoral immunity plays a central role in termination of human babesiosis, and if so, whether there may be a role for passive immunotherapy with IVIG for such patients. Likewise, murine models of babesiosis have underscored the importance of IFN- $\gamma$ to host resistance. Further studies should clarify whether subcutaneous administration of IFN- $\gamma$ is beneficial for people with T-cell deficits who are poorly responsive to standard therapy.

\section{Asymptomatic infection}

Asymptomatic patients should not be treated, even if smears are positive, unless parasitemia persists for longer than three months.[106] Similarly, people who have positive anti-babesial serology, but negative blood smears and negative babesia PCR should not be treated, as they likely already have resolved their infection. Immunocompromised patients experiencing persistent asymptomatic parasitemia should have sequential blood smears performed every several months until they clear infection. 


\section{Prevention}

Strategies to prevent $I$. scapularis transmitted diseases have been the focus of intense study. [10, 113-115] Preventive measures consist of personal, residential, and community approaches. The use of multiple strategies is most likely to be effective.

Personal protective measures include avoiding sites where ticks, deer, and mice are known to thrive, especially from May through October. It is especially important for those at increased risk, such as asplenic or other immunocompromised people who live or travel in endemic areas, to avoid brushy sites where ticks may abound. All those who contact foliage in endemic sites should wear clothing that covers the lower part of the body, cuffs of the trousers should be tucked into stockings, and clothing should be sprayed or impregnated with permethrin (Permanone ${ }^{\circledR}$ ).[116] DEET-containing products should be applied to the skin in the event that the legs remain uncovered. The body should be searched for attached ticks at the end of each period of exposure. Attached ticks should be removed as soon as possible by use of tweezers.[117] In contrast to Lyme disease, there is no data on the use of prophylactic antibiotics after a tick bite to prevent babesiosis nor has a human babesiosis vaccine been developed.

Property modifications such as keeping grass mowed, removing leaf litter at the edge of lawns, and use of plantings that do not attract deer, are just a few landscape management strategies for prevention of tick-borne infection.[114] Fencing may be used to keep deer away and sealing stonewalls can decrease the number of mice on property. Residential land can be treated with acaricidal sprays to brushy sites, such as those that occur at the forest margins. Rodent-targeted acaricides, such as Damminix ® or fipronil, can be used to eliminate ticks that are attempting to feed on mice while a four poster device has been used to apply acaricides to deer.[114, 118] Community efforts to eliminate the local deer population can sharply reduce the risk of infection. Deer were virtually eliminated on Great Island off Cape Cod, Massachusetts, and within 3-5 years the density of I. scapularis ticks fell precipitously.[115] Only one case of babesiosis has been reported from that site since deer reduction. Currently the Red Cross and other blood donation agencies prohibit people with a history of babesiosis from donating blood in order to prevent transfusion-related cases.[119]

\section{Summary}

Human babesiosis is an emerging intraerythrocytic infection caused by protozoal parasites and transmitted by Ixodid ticks. B. microti infections are endemic in the northeastern and upper midwestern regions of the United States. Other babesial species causing human infection in the United States include B. duncani in the western states and B. divergens-like organisms in the midwestern states. Babesiosis is only sporadically reported in Europe where cases are caused by B. divergens, B. microti, and EU1. Other species have been shown to cause disease in Asia, Africa, and South America. Babesial infections range in severity from asymptomatic to severe, and occasionally are fatal. Most symptomatic infections with B. microti are mild and self-limiting, causing a viral-like illness one to six weeks after tick bite. The salient features are fever, malaise, fatigue, chills, sweats, and 
headache. Severe babesiosis may develop in patients with immunodeficiency caused by splenectomy, malignancy, immunosuppressive therapy, or HIV co-infection. Patients older than 50 years or people who experience $B$. divergens or $B$. duncani infections also are at risk for severe disease. Severe babesiosis is associated with a parasitemia $\geq 10 \%$; hemolytic anemia; pulmonary, renal, and hepatic complications; and death. Specific laboratory diagnosis of babesial infections is made by morphological examination of Giemsa stained blood smears, serology, and amplification of babesial DNA using PCR. The combination of atovaquone and azithromycin is the treatment of choice for mild to moderate illness while clindamycin and quinine are indicated for severe disease. Exchange transfusion should be used for life-threatening infection. Although no vaccine has been developed to prevent human babesiosis, a number of other preventive measures have been described.

\section{Acknowledgments}

This work was supported by Grants \# AG19781 (E.V.) and RR06192 (P.J.K.) from the National Institutes of Health. Its contents are solely the responsibility of the authors and do not necessarily represent the official view of the National Institutes of Health.

\section{References}

1. Babes V. Sur l'hemoglobinurie bacterienne du boeuf. Comptes Rendus Acad Sci. 1988; 107:692694.

2. Smith, T.; Kilborne, FL. Bur Anim Indust Bull. US Dept Agr; 1893. Investigations into the nature, causation, and prevention of Texa or southern cattle fever; p. 177-304.

3. Levine ND. Progress in taxonomy of the Apicomplexan protozoa. J Protozool. 1988; 35(4):518-20. [PubMed: 3143826]

4. Skrabalo Z, Deanovic Z. Piroplasmosis in man; report of a case. Doc Med Geogr Trop. 1957; 9(1): 11-6. [PubMed: 13427667]

5. Fitzpatrick JE, Kennedy CC, McGeown MG, et al. Human case of piroplasmosis (babesiosis). Nature. 1968; 217(5131):861-2. [PubMed: 5689184]

6. Western KA, Benson GD, Gleason NN, et al. Babesiosis in a Massachusetts resident. N Engl J Med. 1970; 283(16):854-6. [PubMed: 4989787]

7. Spielman, A. Lyme disease and human babesiosis: evidence incriminating vector and reservoir hosts. In: Englund, PT.; Sher, A., editors. The biology of parasitism. New York: Alan R. Liss; 1988. p. $147-165$.

8. Spielman A, Clifford CM, Piesman J, et al. Human babesiosis on Nantucket Island, USA: description of the vector, Ixodes (Ixodes) dammini, n. sp (Acarina: Ixodidae). J Med Entomol. 1979; 15(3):218-34. [PubMed: 439119]

9. Spielman A, Etkind P, Piesman J, et al. Reservoir hosts of human babesiosis on Nantucket Island. Am J Trop Med Hyg. 1981; 30(3):560-5. [PubMed: 7020449]

10. Spielman A, Wilson ML, Levine JF, et al. Ecology of Ixodes dammini-borne human babesiosis and Lyme disease. Annu Rev Entomol. 1985; 30:439-60. [PubMed: 3882050]

11. Persing DH, Herwaldt BL, Glaser C, et al. Infection with a babesia-like organism in northern California. N Engl J Med. 1995; 332(5):298-303. [PubMed: 7816065]

12. Herwaldt B, Persing DH, Precigout EA, et al. A fatal case of babesiosis in Missouri: identification of another piroplasm that infects humans. Ann Intern Med. 1996; 124(7):643-50. [PubMed: 8607592]

13. Herwaldt BL, Caccio S, Gherlinzoni F, et al. Molecular characterization of a non-Babesia divergens organism causing zoonotic babesiosis in Europe. Emerg Infect Dis. 2003; 9(8):942-8. [PubMed: 12967491] 
14. Shih CM, Liu LP, Chung WC, et al. Human babesiosis in Taiwan: asymptomatic infection with a Babesia microti-like organism in a Taiwanese woman. J Clin Microbiol. 1997; 35(2):450-4. [PubMed: 9003614]

15. Kim JY, Cho SH, Joo HN, et al. First case of human babesiosis in Korea: detection and characterization of a novel type of Babesia sp. (KO1) similar to ovine babesia. J Clin Microbiol. 2007; 45(6):2084-7. [PubMed: 17392446]

16. Perkins ME. Rhoptry organelles of apicomplexan parasites. Parasitol Today. 1992; 8(1):28-32. [PubMed: 15463523]

17. Mackenstedt U, Gauer M, Mehlhorn H, et al. Sexual cycle of Babesia divergens confirmed by DNA measurements. Parasitol Res. 1990; 76(3):199-206. [PubMed: 2315280]

18. Rudzinska MA, Spielman A, Riek RF, et al. Intraerythrocytic 'gametocytes' of Babesia microti and their maturation in ticks. Can J Zool. 1979; 57(2):424-34. [PubMed: 540277]

19. Rudzinska MA, Spielman A, Lewengrub S, et al. The sequence of developmental events of Babesia microti in the gut of Ixodes dammini. Protistologica. 1984; 20(2):649-663.

20. Piesman J, Spielman A. Babesia microti: infectivity of parasites from ticks for hamsters and whitefooted mice. Exp Parasitol. 1982; 53(2):242-8. [PubMed: 7060705]

21. Krause PJ, Telford SR 3rd, Spielman A, et al. Concurrent Lyme disease and babesiosis. Evidence for increased severity and duration of illness. Jama. 1996; 275(21):1657-60. [PubMed: 8637139]

22. Piesman J, Spielman A. Human babesiosis on Nantucket Island: prevalence of Babesia microti in ticks. Am J Trop Med Hyg. 1980; 29(5):742-6. [PubMed: 7435782]

23. Healy G. The impact of cultural and environmental changes on the epidemiology and control of human babesiosis. Trans R Soc Trop Med Hyg. 1989; 83(Suppl):35-8. [PubMed: 2696158]

24. Esernio-Jenssen D, Scimeca PG, Benach JL, et al. Transplacental/perinatal babesiosis. J Pediatr. 1987; 110(4):570-2. [PubMed: 3559805]

25. Fox LM, Wingerter S, Ahmed A, et al. Neonatal babesiosis: case report and review of the literature. Pediatr Infect Dis J. 2006; 25(2):169-73. [PubMed: 16462298]

26. Leiby DA. Babesiosis and blood transfusion: flying under the radar. Vox Sang. 2006; 90(3):15765. [PubMed: 16507014]

27. Eskow ES, Krause PJ, Spielman A, et al. Southern extension of the range of human babesiosis in the eastern United States. J Clin Microbiol. 1999; 37(6):2051-2. [PubMed: 10325378]

28. Herwaldt BL, Neitzel DF, Gorlin JB, et al. Transmission of Babesia microti in Minnesota through four blood donations from the same donor over a 6-month period. Transfusion. 2002; 42(9):11548. [PubMed: 12430672]

29. Krause PJ, Telford SR 3rd, Ryan R, et al. Geographical and temporal distribution of babesial infection in Connecticut. J Clin Microbiol. 1991; 29(1):1-4. [PubMed: 1993742]

30. Meldrum SC, Birkhead GS, White DJ, et al. Human babesiosis in New York State: an epidemiological description of 136 cases. Clin Infect Dis. 1992; 15(6):1019-23. [PubMed: 1457632]

31. Steketee RW, Eckman MR, Burgess EC, et al. Babesiosis in Wisconsin. A new focus of disease transmission. Jama. 1985; 253(18):2675-8. [PubMed: 3886942]

32. Conrad PA, Kjemtrup AM, Carreno RA, et al. Description of Babesia duncani n.sp. (Apicomplexa: Babesiidae) from humans and its differentiation from other piroplasms. Int J Parasitol. 2006; 36(7):779-89. [PubMed: 16725142]

33. Beattie JF, Michelson ML, Holman PJ. Acute babesiosis caused by Babesia divergens in a resident of Kentucky. N Engl J Med. 2002; 347(9):697-8. [PubMed: 12200568]

34. Herwaldt BL, de Bruyn G, Pieniazek NJ, et al. Babesia divergens-like infection, Washington State. Emerg Infect Dis. 2004; 10(4):622-9. [PubMed: 15200851]

35. Foppa IM, Krause PJ, Spielman A, et al. Entomologic and serologic evidence of zoonotic transmission of Babesia microti, eastern Switzerland. Emerg Infect Dis. 2002; 8(7):722-6. [PubMed: 12095442]

36. Gorenflot A, Moubri K, Precigout E, et al. Human babesiosis. Ann Trop Med Parasitol. 1998; 92(4):489-501. [PubMed: 9683900] 
37. Hildebrandt A, Hunfeld KP, Baier M, et al. First confirmed autochthonous case of human Babesia microti infection in Europe. Eur J Clin Microbiol Infect Dis. 2007; 26(8):595-601. [PubMed: 17587072]

38. Meer-Scherrer L, Adelson M, Mordechai E, et al. Babesia microti infection in Europe. Curr Microbiol. 2004; 48(6):435-7. [PubMed: 15170239]

39. Wei Q, Tsuji M, Zamoto A, et al. Human babesiosis in Japan: isolation of Babesia microti-like parasites from an asymptomatic transfusion donor and from a rodent from an area where babesiosis is endemic. J Clin Microbiol. 2001; 39(6):2178-83. [PubMed: 11376054]

40. Marathe A, Tripathi J, Handa V, et al. Human babesiosis--a case report. Indian J Med Microbiol. 2005; 23(4):267-9. [PubMed: 16327127]

41. Bush JB, Isaacson M, Mohamed AS, et al. Human babesiosis--a preliminary report of 2 suspected cases in South Africa. S Afr Med J. 1990; 78(11):699. [PubMed: 2251622]

42. Rios L, Alvarez G, Blair S. Serological and parasitological study and report of the first case of human babesiosis in Colombia. Rev Soc Bras Med Trop. 2003; 36(4):493-8. [PubMed: 12937727]

43. Krause PJ, McKay K, Gadbaw J, et al. Increasing health burden of human babesiosis in endemic sites. Am J Trop Med Hyg. 2003; 68(4):431-6. [PubMed: 12875292]

44. Swanson SJ, Neitzel D, Reed KD, et al. Coinfections acquired from Ixodes ticks. Clin Microbiol Rev. 2006; 19(4):708-27. [PubMed: 17041141]

45. Krause PJ, McKay K, Thompson CA, et al. Disease-specific diagnosis of coinfecting tickborne zoonoses: babesiosis, human granulocytic ehrlichiosis, and Lyme disease. Clin Infect Dis. 2002; 34(9):1184-91. [PubMed: 11941544]

46. Wilson, ME. A world guide to infections: diseases, distribution, diagnosis. New York: Oxford University Press; 1991.

47. Hatcher JC, Greenberg PD, Antique J, et al. Severe babesiosis in Long Island: review of 34 cases and their complications. Clin Infect Dis. 2001; 32(8):1117-25. [PubMed: 11283800]

48. Ruebush TK 2nd, Juranek DD, Chisholm ES, et al. Human babesiosis on Nantucket Island. Evidence for self-limited and subclinical infections. N Engl J Med. 1977; 297(15):825-7. [PubMed: 561308]

49. White DJ, Talarico J, Chang HG, et al. Human babesiosis in New York State: Review of 139 hospitalized cases and analysis of prognostic factors. Arch Intern Med. 1998; 158(19):2149-54. [PubMed: 9801183]

50. Ruebush TK 2nd, Cassaday PB, Marsh HJ, et al. Human babesiosis on Nantucket Island: clinical features. Ann Intern Med. 1977; 86:6-9. [PubMed: 556920]

51. Sun T, Tenenbaum MJ, Greenspan J, et al. Morphologic and clinical observations in human infection with Babesia microti. J Infect Dis. 1983; 148(2):239-48. [PubMed: 6684141]

52. Wittner M, Rowin KS, Tanowitz HB, et al. Successful chemotherapy of transfusion babesiosis. Ann Intern Med. 1982; 96(5):601-4. [PubMed: 7200341]

53. Mathewson HO, Anderson AE, Hazard GW. Self-limited babesiosis in a splenectomized child. Pediatr Infect Dis. 1984; 3(2):148-9. [PubMed: 6539467]

54. Ortiz JM, Eagle RC Jr. Ocular findings in human babesiosis (Nantucket fever). Am J Ophthalmol. 1982; 93(3):307-11. [PubMed: 7200325]

55. Krause PJ, Gewurz BE, Hill D, et al. Persistent and relapsing babesiosis in immunocompromised patients. Clin Infect Dis. 2008; 46(3):370-6. [PubMed: 18181735]

56. Krause PJ, Spielman A, Telford SR 3rd, et al. Persistent parasitemia after acute babesiosis. N Engl J Med. 1998; 339(3):160-5. [PubMed: 9664092]

57. Benezra D, Brown AE, Polsky B, et al. Babesiosis and infection with human immunodeficiency virus (HIV). Ann Intern Med. 1987; 107(6):944. [PubMed: 3688692]

58. Falagas ME, Klempner MS. Babesiosis in patients with AIDS: a chronic infection presenting as fever of unknown origin. Clin Infect Dis. 1996; 22(5):809-12. [PubMed: 8722936]

59. Froberg MK, Dannen D, Bakken JS. Babesiosis and HIV. Lancet. 2004; 363(9410):704. [PubMed: 15001329] 
60. Haselbarth K, Tenter AM, Brade V, et al. First case of human babesiosis in Germany - Clinical presentation and molecular characterisation of the pathogen. Int J Med Microbiol. 2007; 297(3): 197-204. [PubMed: 17350888]

61. Rosner F, Zarrabi MH, Benach JL, et al. Babesiosis in splenectomized adults. Review of 22 reported cases. Am J Med. 1984; 76(4):696-701. [PubMed: 6424470]

62. Stowell CP, Gelfand JA, Shepard JA, et al. Case records of the Massachusetts General Hospital. Case 17-2007. A 25-year-old woman with relapsing fevers and recent onset of dyspnea. N Engl J Med. 2007; 356(22):2313-9. [PubMed: 17538091]

63. Vannier E, Borggraefe I, Telford SR 3rd, et al. Age-associated decline in resistance to Babesia microti is genetically determined. J Infect Dis. 2004; 189(9):1721-8. [PubMed: 15116311]

64. Zintl A, Mulcahy G, Skerrett HE, et al. Babesia divergens, a bovine blood parasite of veterinary and zoonotic importance. Clin Microbiol Rev. 2003; 16(4):622-36. [PubMed: 14557289]

65. Filstein MR, Benach JL, White DJ, et al. Serosurvey for human babesiosis in New York. J Infect Dis. 1980; 141(4):518-21. [PubMed: 7189538]

66. Hsu NH, Cross JH. Serologic survey for human babesiosis on Taiwan. Taiwan Yi Xue Hui Za Zhi. 1977; 76(12):950-4. [PubMed: 273657]

67. Yokoyama N, Okamura M, Igarashi I. Erythrocyte invasion by Babesia parasites: current advances in the elucidation of the molecular interactions between the protozoan ligands and host receptors in the invasion stage. Vet Parasitol. 2006; 138(1-2):22-32. [PubMed: 16504403]

68. Lobo CA. Babesia divergens and Plasmodium falciparum use common receptors, glycophorins A and B, to invade the human red blood cell. Infect Immun. 2005; 73(1):649-51. [PubMed: 15618210]

69. O'Connor RM, Lane TJ, Stroup SE, et al. Characterization of a variant erythrocyte surface antigen (VESA1) expressed by Babesia bovis during antigenic variation. Mol Biochem Parasitol. 1997; 89(2):259-70. [PubMed: 9364970]

70. Allred DR. Babesiosis: persistence in the face of adversity. Trends Parasitol. 2003; 19(2):51-5. [PubMed: 12586467]

71. Allred DR, Al-Khedery B. Antigenic variation and cytoadhesion in Babesia bovis and Plasmodium falciparum: different logics achieve the same goal. Mol Biochem Parasitol. 2004; 134(1):27-35. [PubMed: 14747140]

72. O'Connor RM, Allred DR. Selection of Babesia bovis-infected erythrocytes for adhesion to endothelial cells co-selects for altered variant erythrocyte surface antigen isoforms. J Immunol. 2000; 164(4):2037-45. [PubMed: 10657656]

73. Kyes S, Horrocks P, Newbold C. Antigenic variation at the infected red cell surface in malaria. Annu Rev Microbiol. 2001; 55:673-707. [PubMed: 11544371]

74. Dao AH, Eberhard ML. Pathology of acute fatal babesiosis in hamsters experimentally infected with the WA-1 strain of Babesia. Lab Invest. 1996; 74(5):853-9. [PubMed: 8642781]

75. Everitt JI, Shadduck JA, Steinkamp C, et al. Experimental Babesia bovis infection in Holstein calves. Vet Pathol. 1986; 23(5):556-62. [PubMed: 3776013]

76. Hemmer RM, Wozniak EJ, Lowenstine LJ, et al. Endothelial cell changes are associated with pulmonary edema and respiratory distress in mice infected with the WA1 human Babesia parasite. J Parasitol. 1999; 85(3):479-89. [PubMed: 10386441]

77. Clark IA, Budd AC, Hsue G, et al. Absence of erythrocyte sequestration in a case of babesiosis in a splenectomized human patient. Malar J. 2006; 5:69. [PubMed: 16887045]

78. Fitzpatrick JE, Kennedy CC, McGeown MG, et al. Further details of third recorded case of redwater (Babesiosis) in man. Br Med J. 1969; 4(5686):770-2. [PubMed: 4902497]

79. Chen D, Copeman DB, Burnell J, et al. Helper T cell and antibody responses to infection of CBA mice with Babesia microti. Parasite Immunol. 2000; 22(2):81-8. [PubMed: 10652120]

80. Goff WL, Johnson WC, Tuo W, et al. Age-related innate immune response in calves to Babesia bovis involves IL-12 induction and IL-10 modulation. Ann N Y Acad Sci. 2002; 969:164-8. [PubMed: 12381584]

81. Aguilar-Delfin I, Wettstein PJ, Persing DH. Resistance to acute babesiosis is associated with interleukin-12- and gamma interferon-mediated responses and requires macrophages and natural killer cells. Infect Immun. 2003; 71(4):2002-8. [PubMed: 12654819] 
82. Clawson ML, Paciorkowski N, Rajan TV, et al. Cellular immunity, but not gamma interferon, is essential for resolution of Babesia microti infection in BALB/c mice. Infect Immun. 2002; 70(9): 5304-6. [PubMed: 12183588]

83. Igarashi I, Waki S, Ito M, et al. Role of $\mathrm{CD}^{+}{ }^{+} \mathrm{T}$ cells in the control of primary infection with Babesia microti in mice. J Protozool Res. 1994; 4:164-171.

84. Wood PR, Clark IA. Apparent irrelevance of NK cells to resolution of infections with Babesia microti and Plasmodium vinckei petteri in mice. Parasite Immunol. 1982; 4(5):319-27. [PubMed: 7145462]

85. Rosenblatt-Bin H, Klein A, Sredni B. Antibabesial effect of the immunomodulator AS101 in mice: role of increased production of nitric oxide. Parasite Immunol. 1996; 18(6):297-306. [PubMed: 9229382]

86. Shoda LK, Palmer GH, Florin-Christensen J, et al. Babesia bovis-stimulated macrophages express interleukin-1 $\beta$, interleukin-12, tumor necrosis factor alpha, and nitric oxide and inhibit parasite replication in vitro. Infect Immun. 2000; 68(9):5139-45. [PubMed: 10948137]

87. Stich RW, Rice-Ficht AC, Tuo W, et al. Babesia bovis: common protein fractions recognized by oligoclonal B. bovis-specific CD4 ${ }^{+} \mathrm{T}$ cell lines from genetically diverse cattle. Exp Parasitol. 1999; 91(1):40-51. [PubMed: 9920041]

88. Goff WL, Johnson WC, Parish SM, et al. IL-4 and IL-10 inhibition of IFN- $\gamma$ - and TNF- $\mathrm{a}-$ dependent nitric oxide production from bovine mononuclear phagocytes exposed to Babesia bovis merozoites. Vet Immunol Immunopathol. 2002; 84(3-4):237-51. [PubMed: 11777537]

89. Hemmer RM, Ferrick DA, Conrad PA. Up-regulation of tumor necrosis factor-alpha and interferon-gamma expression in the spleen and lungs of mice infected with the human Babesia isolate WA1. Parasitol Res. 2000; 86(2):121-8. [PubMed: 10685843]

90. Clark IA, Alleva LM, Mills AC, et al. Pathogenesis of malaria and clinically similar conditions. Clin Microbiol Rev. 2004; 17(3):509-39. [PubMed: 15258091]

91. Krause PJ, Daily J, Telford SR, et al. Shared features in the pathobiology of babesiosis and malaria. Trends Parasitol. 2007; 23(12):605-10. [PubMed: 17988944]

92. Hanafusa Y, Onuma M, Kamiyama T. Partial protection of severe combined immunodeficient mice against infection with Babesia microti by in vitro-generated $\mathrm{CD} 4^{+} \mathrm{T}$ cell clones. J Vet Med Sci. 1998; 60(4):401-4. [PubMed: 9592710]

93. Hemmer RM, Ferrick DA, Conrad PA. Role of T cells and cytokines in fatal and resolving experimental babesiosis: protection in TNFRp55-/- mice infected with the human Babesia WA1 parasite. J Parasitol. 2000; 86(4):736-42. [PubMed: 10958449]

94. Shimada T, Shikano S, Hashiguchi R, et al. Effects of depletion of T cell subpopulations on the course of infection and anti-parasite delayed type hypersensitivity response in mice infected with Babesia microti and Babesia rodhaini. J Vet Med Sci. 1996; 58(4):343-7. [PubMed: 8741267]

95. Cavacini LA, Parke LA, Weidanz WP. Resolution of acute malarial infections by T cell-dependent non-antibody-mediated mechanisms of immunity. Infect Immun. 1990; 58(9):2946-50. [PubMed: 2387628]

96. Igarashi I, Suzuki R, Waki S, et al. Roles of $\mathrm{CD}^{+} \mathrm{T}$ cells and gamma interferon in protective immunity against Babesia microti infection in mice. Infect Immun. 1999; 67(8):4143-8. [PubMed: 10417185]

97. Matsubara J, Koura M, Kamiyama T. Infection of immunodeficient mice with a mouse-adapted substrain of the Gray strain of Babesia microti. J Parasitol. 1993; 79(5):783-6. [PubMed: 8410556]

98. Healy GR, Ruebush TK 2nd. Morphology of Babesia microti in human blood smears. Am J Clin Pathol. 1980; 73(1):107-9. [PubMed: 7188717]

99. Krause PJ, Telford S 3rd, Spielman A, et al. Comparison of PCR with blood smear and inoculation of small animals for diagnosis of Babesia microti parasitemia. J Clin Microbiol. 1996; 34(11): 2791-4. [PubMed: 8897184]

100. Persing DH, Mathiesen D, Marshall WF, et al. Detection of Babesia microti by polymerase chain reaction. J Clin Microbiol. 1992; 30(8):2097-103. [PubMed: 1500517]

101. Krause PJ, Ryan R, Telford S 3rd, et al. Efficacy of immunoglobulin M serodiagnostic test for rapid diagnosis of acute babesiosis. J Clin Microbiol. 1996; 34(8):2014-6. [PubMed: 8818902] 
102. Krause PJ, Telford SR 3rd, Ryan R, et al. Diagnosis of babesiosis: evaluation of a serologic test for the detection of Babesia microti antibody. J Infect Dis. 1994; 169(4):923-6. [PubMed: 8133112]

103. Ruebush TK 2nd, Chisholm ES, Sulzer AJ, et al. Development and persistence of antibody in persons infected with Babesia microti. Am J Trop Med Hyg. 1981; 30(1):291-2. [PubMed: 7011069]

104. Homer MJ, Aguilar-Delfin I, Telford SR 3rd, et al. Babesiosis. Clin Microbiol Rev. 2000; 13(3): 451-69. [PubMed: 10885987]

105. Krause PJ, Lepore T, Sikand VK, et al. Atovaquone and azithromycin for the treatment of babesiosis. N Engl J Med. 2000; 343(20):1454-8. [PubMed: 11078770]

106. Wormser GP, Dattwyler RJ, Shapiro ED, et al. The clinical assessment, treatment, and prevention of lyme disease, human granulocytic anaplasmosis, and babesiosis: clinical practice guidelines by the Infectious Diseases Society of America. Clin Infect Dis. 2006; 43(9):1089-134. [PubMed: 17029130]

107. Raju M, Salazar JC, Leopold H, et al. Atovaquone and azithromycin treatment for babesiosis in an infant. Pediatr Infect Dis J. 2007; 26(2):181-3. [PubMed: 17259886]

108. Raoult D, Soulayrol L, Toga B, et al. Babesiosis, pentamidine, and cotrimoxazole. Ann Intern Med. 1987; 107(6):944. [PubMed: 3500663]

109. Cahill KM, Benach JL, Reich LM, et al. Red cell exchange: treatment of babesiosis in a splenectomized patient. Transfusion. 1981; 21(2):193-8. [PubMed: 7194528]

110. Jacoby GA, Hunt JV, Kosinski KS, et al. Treatment of transfusion-transmitted babesiosis by exchange transfusion. N Engl J Med. 1980; 303(19):1098-100. [PubMed: 7191475]

111. Powell VI, Grima K. Exchange transfusion for malaria and Babesia infection. Transfus Med Rev. 2002; 16(3):239-50. [PubMed: 12075561]

112. Vyas JM, Telford SR, Robbins GK. Treatment of refractory Babesia microti infection with atovaquone-proguanil in an HIV-infected patient: case report. Clin Infect Dis. 2007; 45(12): 1588-90. [PubMed: 18190320]

113. Hayes EB, Piesman J. How can we prevent Lyme disease? N Engl J Med. 2003; 348(24):242430. [PubMed: 12802029]

114. Stafford, KC, 3rd. Tick management handbook: an integrated guide for homeowners, pest control operators, and public health officials for the prevention of tick-associated disease. CAES Publication; 2004.

115. Wilson ML, Telford SR 3rd, Piesman J, et al. Reduced abundance of immature Ixodes dammini (Acari: Ixodidae) following elimination of deer. J Med Entomol. 1988; 25(4):224-8. [PubMed: 3404540]

116. Smith RD, Kakoma I. A reappraisal of vector control strategies for babesiosis. Trans R Soc Trop Med Hyg. 1989; 83(Suppl):43-52. [PubMed: 2696160]

117. Needham GR. Evaluation of five popular methods for tick removal. Pediatrics. 1985; 75(6):9971002. [PubMed: 4000801]

118. Mather TN, Ribeiro JM, Spielman A. Lyme disease and babesiosis: acaricide focused on potentially infected ticks. Am J Trop Med Hyg. 1987; 36(3):609-14. [PubMed: 3555140]

119. McQuiston JH, Childs JE, Chamberland ME, et al. Transmission of tick-borne agents of disease by blood transfusion: a review of known and potential risks in the United States. Transfusion. 2000; 40(3):274-84. [PubMed: 10738026] 


\section{Synopsis}

Human babesiosis is an emerging intraerythrocytic infection caused by protozoal parasites and transmitted by Ixodid ticks. Babesiosis is endemic in the northeastern and upper midwestern regions of the United States and found sporadically in other parts of the United States, Europe, Asia, Africa, and South America. Babesial infections range in severity from asymptomatic to severe, and occasionally are fatal. Specific laboratory diagnosis of babesial infections is made by morphological examination of Giemsa stained blood smears, serology, and amplification of babesial DNA using PCR. The combination of atovaquone and azithromycin is the treatment of choice for mild to moderate illness while clindamycin and quinine are indicated for severe disease. 


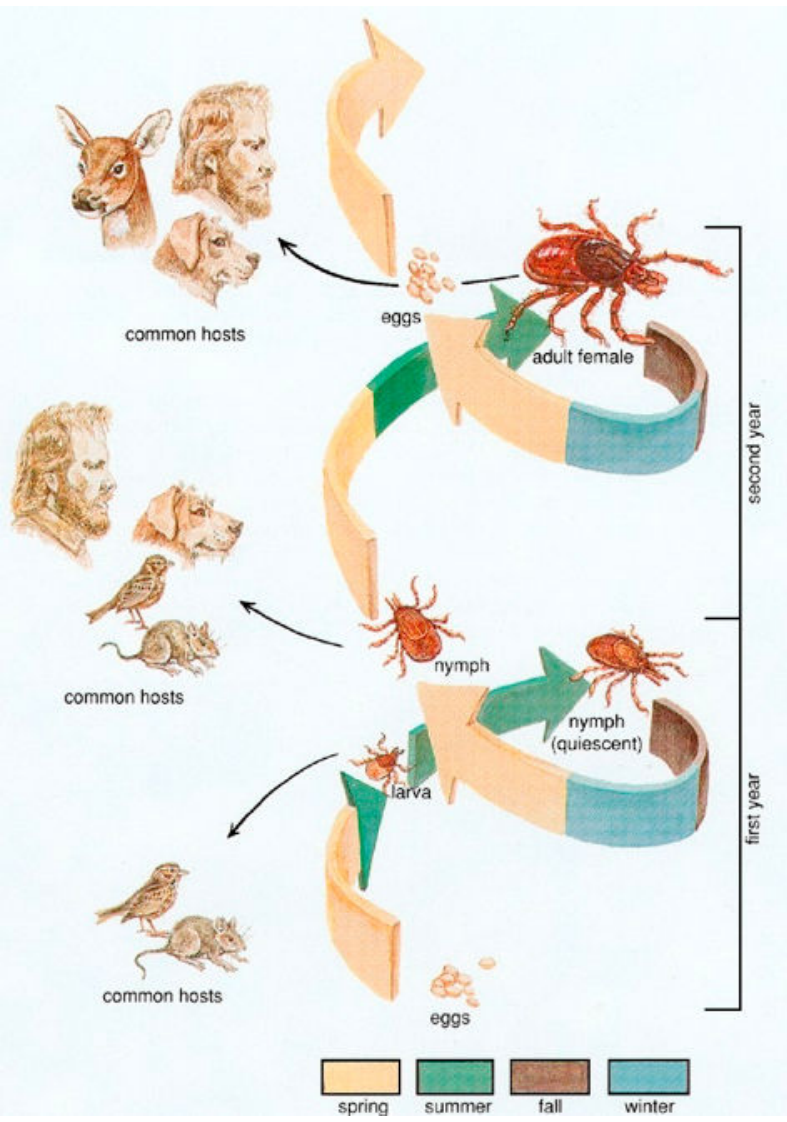

Figure 1. Life cycle of the Ixodes scapularis tick 


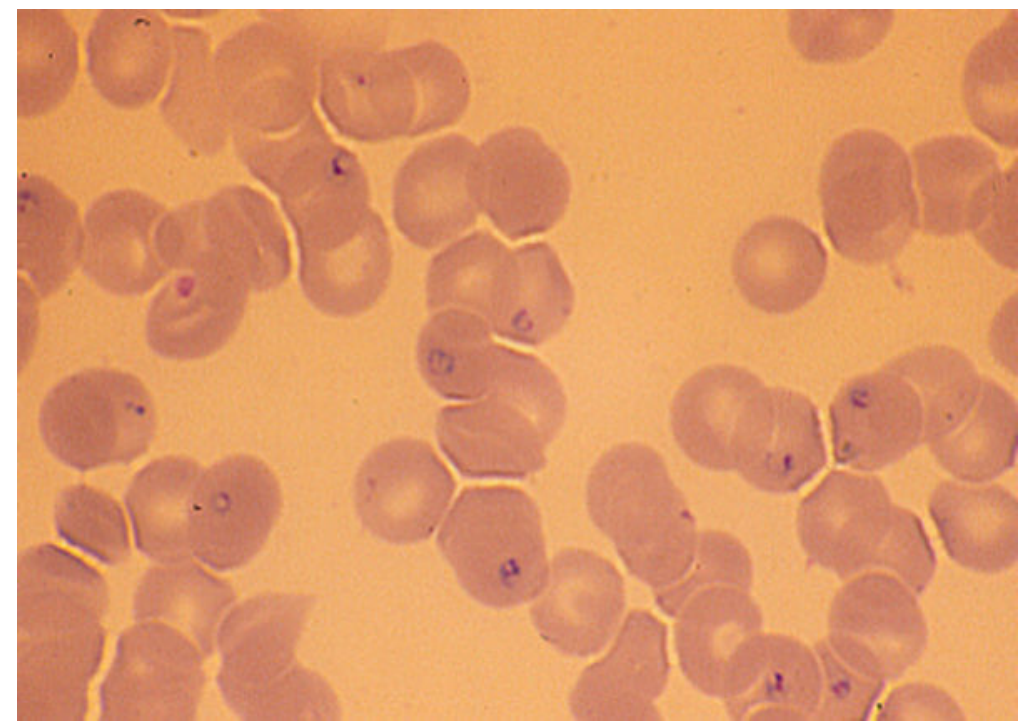

Figure 2. Ring forms of Babesia microti in human blood smear $(\times 1000)$ 


\section{Table 1}

Symptoms of babesiosis

\begin{tabular}{lccc}
\hline Symptom & Outpatient $(\mathbf{n}=\mathbf{4 1})$ & Inpatient $(\mathbf{n}=\mathbf{1 7 3})$ & Total $(\mathbf{n}=\mathbf{2 1 4})$ \\
Fever & 68 & 89 & 85 \\
Fatigue & 78 & 79 & 79 \\
Chills & 39 & 68 & 63 \\
Sweats & 41 & 56 & 53 \\
Headache & 75 & 32 & 39 \\
Myalgia & 37 & 32 & 33 \\
Anorexia & 25 & 24 & 24 \\
Cough & 17 & 23 & 22 \\
Arthralgia & 31 & 17 & 18 \\
Nausea & 22 & 9 & 16 \\
\hline
\end{tabular}

Outpatient cases are from Ruebush et al. [50] and Krause et al. [21]. Inpatient cases are from White et al. [49] and Hatcher et al. [47]. 
Table 2

Complications of babesiosis in 34 consecutive hospitalized patients

\begin{tabular}{lr}
\hline Complication & Frequency (\%) \\
Acute respiratory failure & 21 \\
DIC & 18 \\
Congestive heart failure & 12 \\
Coma/lethargy & 9 \\
Renal failure & 6 \\
Death & 9 \\
\hline
\end{tabular}

The mean age of patients was 53 years, median age 43 years, range 3 months to 85 years. From Hatcher et al. [47] 
Table 3

\section{Treatment of babesiosis}

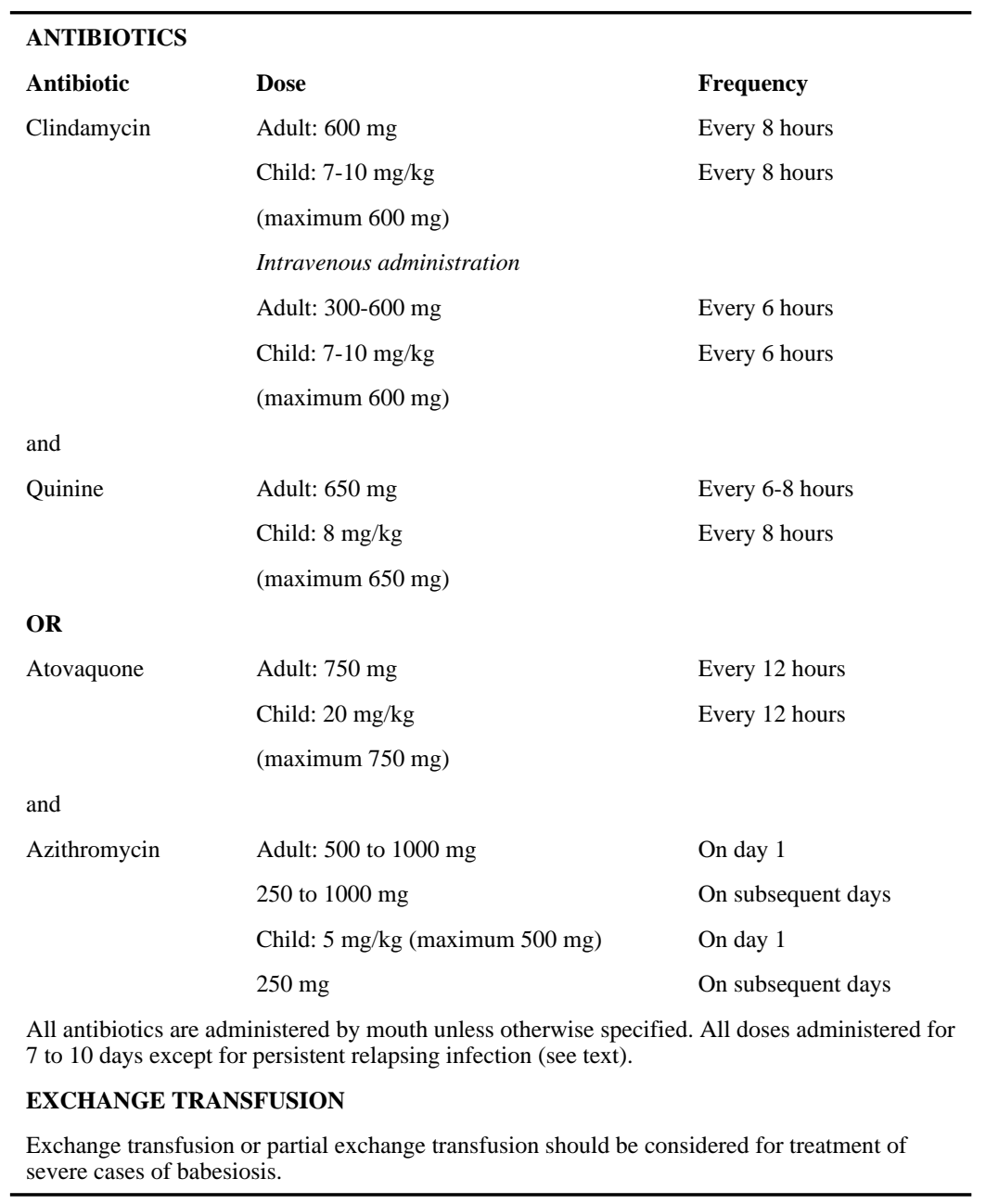

